\title{
The efFect Of Using SWEet POTATO AND PUMPKIN GRITS ON PRODUCING CORN SNACKS BY EXTRUSION COOKING.
}

\author{
By \\ EL-Zeiny, A., $R$. \\ Home economic dept, Faculty of \\ Specific Education, Mansoura \\ University, Egypt. \\ Abdeen, E. M. \\ Food Technology Research Institute, \\ Agriculture Research Central, Dokki, \\ Giza- Egypt. \\ Ramadan, Afaf-Haniem, $M$. \\ Home economic dept, Faculty of \\ Specific Education, Mansoura \\ University, Egypt. \\ Abo Mandour, Hanan \\ Home economic dept, Faculty of \\ Specific Education, Mansoura \\ University, Egypt.
}

Research gournal Specific Fducation

Faculty of Specific Education

gYansoura University

ISSUE NO. 31, JULY. 2013

مجلة بحوث التربية النوعية ـ جامعة المنصورة

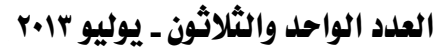




\title{
The effect of Using SWeet Potato and PuMpkin GRItS ON PRODUCING CORN SNACKS BY EXTRUSION COOKING
}

EL-Zeiny, A., R. ${ }^{*}$

Abdeen, E. M.*
Ramadan, Afaf-Haniem, M.

Abo Mandour, Hanan *

\begin{abstract}
This work was carried out to study effect substitution of corn grits with $5 \%$ sweet potato or pumpkin grits for processing corn snacks using extrusion cooking techniques . The most favorable conditions for operator device were determined namely: feed moisture content, speed screw and extruder barrel temperature .Sensory evaluation such as color, taste, appearance, crispness and over all acceptability on the final product characteristics were studied. Three factors were identified for the operation as follows :feed moisture contents(16, 18 and 20\%), screw speed(120, 140, 160rpm) and barrel temperature $\left(130,150\right.$ and $\left.170{ }^{\circ} \mathrm{C}\right)$ and the impact on the physicochemical properties such as bulk density (BD), expansion rate(ER) and water solubility index \%( WSI \%). The results indicated that the suitable expansion ratio were 2.01 and $2.62 \mathrm{gm} / \mathrm{cm} 3$ and the swelling percentage were 3.5 to $3.4 \%$, respectively checks at $16 \%$ and $18 \%$ moisture for blend snacks1 ( $95 \%$ corn grits $+5 \%$ sweet potato grits )and blend snacks 2 ( $95 \%$ corn grits $+5 \%$ pumpkin grits), while the proper screw speed ( 120 and $140 \mathrm{rpm}$ ) by high barrel temperature ( 130 and $150 \mathrm{oc}$ ). The results showed significant differences in the color, taste, appearance, crispness and over all acceptability in each of the blend 1 and 2 as compared to the control (100\% corn grits snacks) and had a best appearance of the blend 1 and the highest values for color, taste and over all acceptability for the blend 2. So, it can be concluded that the process of extrusion device cooking heat the most suitable for operation is content feed humidity $16 \%$ ,temperature $130{ }^{\circ} \mathrm{C}$ and the speed screw120rpm for a blend1 and $18 \%$

\footnotetext{
Home economic dept, Faculty of Specific Education, Mansoura University, Egypt.

"Food Technology Research Institute, Agriculture Research Central, Dokki, Giza- Egypt.
} 
moisture, $150^{\circ} \mathrm{c}$ and $140 \mathrm{rpm}$ for the blend 2 to produce a product acceptable corn Snacks, and on the other the use of $5 \%$ of the sweet potatoes grits or pumpkin grits for the production of corn snacks contributed positively to show the desired qualities of a product such as increasing the expansion rate , improved crispness, taste and overall acceptability. This study highlights the importance of the selection experimentally the impact of new ingredients on different variables when manufacturing snacks from corn snacks.

Keywords: Extrusion, Snacks, Screw Speed, Sweet Potato, Pumpkin, Corn grits and sensory. 


\section{The efFEct Of Using SWEet POTATO AND PUMPKIN GRITS ON PRODUCING CORN SNACKS BY EXTRUSION COOKING}

EL-Zeiny, A., R. ${ }^{*}$

Abdeen, E. M. ${ }^{* *}$
Ramadan, Afaf-Haniem, M.

Abo Mandour, Hanan

\section{Introduction:-}

Extrusion cooking has been used increasingly in the production of food and food ingredients such as breakfast cereals baby foods, flats breads and snacks (Meuser and Van Lengerich, 1992).Snack, defined as a light meal eaten between regular meals include a broad range of products that can take many forms ( Sajilata and singhal, 2004).

Extrusion cooking as a continuous cooking, mixing, and forming process, is a versatile, low cost, and very efficient technology in food processing. During extrusion cooking, the raw materials undergo many chemical and structural transformations, such as starch gelatinization, protein denaturation, complex formation between amylose and lipids, and degradation reactions of vitamins, pigments, etc (Ilo et al. , 1999). Despite increase use of extrusion processing, extrusion is still a complicated process that has yet to be mastered. Small variations in processing conditions affect process variables as well as product quality (Desrumaux et al ., 1999).

In recent years, there is an increasing demand for conversion of fruit and vegetable wastes into useful products. The primary motivation is to minimize environmental impact of these by-products and to utilize valuable constituents that remain, such as lycopene and dietary fiber. One viable method for utilization of fruit and vegetable by-products into useful products is extrusion processing due to its versatility, high productivity, relative low cost, energy efficiency and lack of effluents (Alton et al.,2007).

For crispy extruded snacks one of the most desirable physical properties is the degree of expansion because it determines their structure

\footnotetext{
"Home economic dept, Faculty of Specific Education, Mansoura University, Egypt.

" Food Technology Research Institute, Agriculture Research Central, Dokki, Giza- Egypt.
} 
and consequently their quality .Expansion of extrudates can vary considerably depending on both processing conditions and feed composition (Martin et al .,2010).

The knowledge of the nutritive value of food, particularly fruits and vegetables, is necessary in order to encourage the increase in their consumption, and their use for nutritional and technological applications. Sweet potato is one of the five most important food crops in developing countries (FAO, 2006). It are cheaper than other crops as starch source, yet this abundant resource is still not properly utilized (Utomo et al., 2005).Thus, red and orange-fleshed sweet potatoes could be used as novel sources of natural colorants and antioxidants with added value for the food industry and human health (Regilda et al., 2007).

Pumpkin is one of the vegetables that meet the requirements of healthy nutrition. It is a tasty and valuable vegetable crop, containing a lot of biologically active substances and distinguished for dietary qualities. The name 'pumpkin' is commonly used for cucurbits of some species, similar in botanical characteristics (Marck et al.,2008). Pumpkin is a good source of carotene, water-soluble vitamins and amino acids. It is relatively low in total solids, usually ranging between $7 \%$ and $10 \%$ (Arévalo-Pinedo and Murr, 2006. and Alibas, 2007).

Exact definitions of the terms do not exist, but there is general consensus that the sensory sensations crispy and crunchy are related to the facture properties of the food products (Vincent, 1998). For a product to be 'crispy' and 'crunchy' the texture should be, in physical terms, firm and brittle, the product has to fracture and disintegrate abruptly and completely during biting and chewing, while the sound emission during biting and mastication has a large effect on the sensory perception of this type of product such as bread and snack cited from (Luyten et al., 2004; Rouelaut et al .,2002 ; Dijksterhuis et al ., 2005 ) . 
The single screw extrusion of raw materials to produce corn snacks and ready-to-eat (RTE) cereals has increased significantly owing to favorable economics and product quality (Onwulata and Konstance, 2006).

Incorporation of by-products from the food industry using extrusion technology in order to improve the nutritional characteristics of ready-to-eat snacks is very well documented (Stojceska et al ., 2008).

Consumers demand nutritious, convenient, tasty snacks that satisfy their hunger momentarily until the next meal .Snack, a food product that fits these criteria, continue to increase in sales (Burn, 2007). Snack nutritional profile of calories, fat, carbohydrate and protein as well as vitamins and minerals are being sought that include fiber (King, 2006).

The objectives of the current study were to ( a) investigate the most favorable conditions for operator device such as : moisture content, speed screw and extruder barrel temperature on the resulting physical properties of extrudate and (b) to study sensorial characteristics of snacks produced by extrusion cooking potato, pumpkin and corn grits blends, production of new snacks, and no effluents or waste .

\section{MATERIALS AND METHODS:-}

\section{Materials:}

Corn grits (yellow) was supplied by Senyorita for Industries (A member company of Americana Group) imported from Italy,. Sweet potato (Ipomoea batatas, (L)), and pumpkin (Cucurbita moschata) were purchased from a local market in Mansoura,

\section{Methods:}

Preparation of sweet potato and pumpkin grits:-

Fresh sweet potato were cleaned and washed with distilled water, peeled, and cut $1 \mathrm{~mm}$ thick slices with a conventional food slicing machine and dried fresh slices in an air circulation dryer model ( Office in specialized GARBUIO, Essiccatioi , TREISO, ITALY ) by used the air heating system at 50 口 C for $4 \mathrm{hr}$. according to Meot et al . ( 2007). 
Pumpkin was washed with distilled water, and cut radically into sections. After removal of seeds, peeled sections were cut into small pieces and dried at dryer model ( Office in specialized GARBUIO ,Essiccatioi , TREISO , ITALY)at $50{ }^{\circ} \mathrm{c}$ for $24 \mathrm{hr}$ according to Zakey . ( 2000).

Formulation of blends:-The percentage of ingredients used in blends preparation is given in Table (1).

Table (1): Recipes for preparing blends.

\begin{tabular}{||c||c|c||}
\hline Ingredient & 1 & 2 \\
\hline \hline Corn grits & 95 & 95 \\
\hline Sweet potato grits (S.P.) & 5 & - \\
\hline Pumpkin grits (p.p) & - & 5 \\
\hline
\end{tabular}

For each blend, the calculated amount of each ingredient was weighed and all ingredients were blended using pilot plant mixer. The blends were packaged in polyamide pouches and kept at refrigerator temperature (3 $4^{\circ} \mathrm{c}$ ) for further analysis using extruder specification.

A single-screw extruder( Fig. 1; Brabender Plastic order, model PL 2000, South Hackensack. NJ), which had a compression ratio of 3:1, screw Length-to Diameter (L/D) ratio of $20: 1$ and a barrel length of $317.5 \mathrm{~mm}$. The die had a diameter of $2.90 \mathrm{~mm}$, with a length of $9.25 \mathrm{~mm}$, which resulted in a die $\mathrm{L} / \mathrm{D}$ of 3.19. The temperature inside the barrel and speed of the screw were controlled by a computer that was connected to the extruder . The extruder was connected to a 7.5 HP motor and the speed of the screw was capable of adjusting from 0-210 rpm (0-22 $\left.\mathrm{rad} \mathrm{s}^{-1}\right)$. 


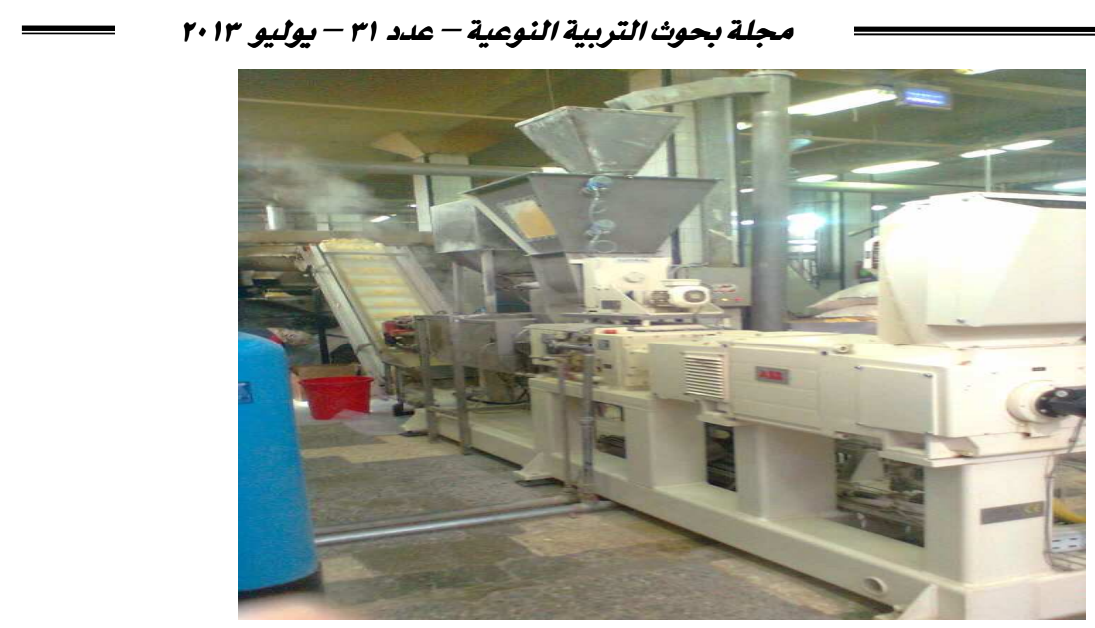

(Fig.1. The single screw extruder).

Extruder was equipped with four barrel zones .The temperatures in these zones were $0^{\circ} \mathrm{c}, 130^{\circ} \mathrm{c}, 150^{\circ} \mathrm{c}$ and $170^{\circ} \mathrm{c}$. The residence time was 30 sec with pressure 30-35 bar. The extruder speed, moisture added and steam flow were 120,140 to $160 \mathrm{rpm}$., 0.1 to $0.2 \mathrm{~kg} / 30 \mathrm{~mm}$ and $4-12.5 \mathrm{~kg} / \mathrm{min}$, respectively .The extruded blends were ground to pass through a $50-$ mesh sieve .After processing, the extradates were allowed to cool and dry under ambient conditions for approximately $24 \mathrm{~h}$, then sealed in polyamide pouches until measurements were taken, according to EOSQ 1525 (2005) .

\section{Technological methods:-}

\section{Sample conditioning:-}

The amount of water necessary to bring 1000 grams of blends grits to the desired moisture level for extrusion was calculated as follow:

$$
\text { Water add }(\mathrm{g})=\frac{\text { moisture desired } \%-\text { moisture in sample } \%}{100-\text { moisture desired } \%} \times 10^{-3}
$$

Water was added to the samples by a sprayer and mixed. The samples were then placed in plastic sealed bags, being maintained for 12 hours before extrusion. 


\section{Physicochemical properties:-}

The resultant products were subjected to an extensive analysis of physicochemical properties, namely expansion ratio (ER), bulk density (BD), and water solubility index \% (WSI\%).

Expansion Ratio (ER) of the extrudate was determined by the method reported by Gujska and Khan ( 1990), using the following equation.

$$
\text { Expansion ratio }(E R)=\frac{\text { Diameter of extruded product }}{\text { Diameter of die of extruder }} \quad\left(\mathrm{g} / \mathrm{cm}^{3}\right)
$$

Bulk density (BD) was measured using a standard Bushel tester ('Seedburo Equipment Co., Chicago, IL), the method was described by USDA (1999).

Water solubility index \% (WSI \%) (Percent of dry sample in water layer) were determined according to Anderson et al. (1981).Two grams of the sample were suspended in $30 \mathrm{ml}$ of water in a $50 \mathrm{ml}$ tarred centrifuge tube at $30^{\circ} \mathrm{C}$. Then stirred intermittently for 30 minutes, and centrifuged at $3000 \mathrm{xg}$ for 10 minutes. The supernatant liquid was carefully poured into a tarred evaporating dish. The remaining gel was weighed and the WAI was calculated. The amount of dried solids recovered by evaporating the supernatant from the water absorption test was expressed as percentage of dry solids. WSI\% was calculated according to the following equations.

$$
\text { Water solubility index } \%(\text { WSI } \%)=\frac{\text { Solids weight }}{\text { Weight of sample }} \times 100
$$

Proximate analysis, Moisture, crude protein, fat, fiber and ash were determined according to the A.O.A. C (2000). Carbohydrate contents were determined by subtracting the difference as follow: Carbohydrates $\%=100-$ ( Moisture $\%+$ protein $\%+$ crude fat $\%+$ crude fiber $\%+$ ash $\%$ ). All analyses were carried out triplicate. 


\section{Sensory evaluation:}

The organoleptic characteristics were carried out according to the methods described by Bates et al. ( 1991) the snacks formula were evaluated by ten member at Home economic dept. Faculty of specific education Mansoura University. Sensory panel testers, ten point hedonic scale for taste, texture, appearance, color and over all acceptability were used.

\section{Statistically analysis:}

Values represented are the means and standard error, significance was used at p. $<0.01$, ANOVA was done using SPSS . (2007) program for windows.

\section{Results and discussion:}

Table 2 showed the chemical composition of the ingredients used in blends preparation Of corn snacks. The moisture contents were10.58 \pm 0.03 , $10.19 \pm 0.27$ and $8.82 \pm 0.05$, respectively in all grits such as corn, sweet potato and pumpkin. These results were in the rang previously attained by Zaky (2000) and Grabowski et al. (2008), they reported that sweet potato grits had 8.9 and $3.7 \%$ moisture content, respectively. Moreover, pumpkin grits contained $8.77 \%$ moisture. Meanwhile, results of Hassan. (2006), Jun et al . (2006) and USDA.( 2009) are coincided with our findings. Soliman (2004) reported that corn grits contained 10. 64\% moisture. The highest protein content $(9.35 \pm 0.02)$ was found in corn grits, while the lowest $(4.48 \pm 0.02 \& 3.75 \pm 0.05)$ were found in sweet potato and pumpkin grits .These results are in accordance to Soliman (2004) who found that protein content of corn grits was $8.92 \pm 0.38 \%$, while Ramadan,et al.(2010) reported that sweet potato flour and pumpkin flour contained $4.50 \pm 0.73$ and $3.80 \pm 0.55 \%$ protein respectively. The highest ash percentage was observed in pumpkin grits followed by sweet potato and grits, it had been $6.30 \pm 0.30$, $3.58 \pm 0.02$ and $1.93 \pm 0.03 \%$, respectively. These results are in the range of data obtained by USDA ( 2009). Concerning carbohydrate data revealed that corn grits, sweet potato grits and pumpkin grits had $82.69 \pm 0.08,85.52 \pm 0.28$ and $84.58 \pm 0.45 \%$, respectively. These results are similar reports by 
Soliman (2004) , Ahmed et al. (2010) and Pongjantaet al. (2006).The highest amount fiber was detected in sweet potato grits, followed by pumpkin grits and corn grits. It was $(5.12 \pm 0.05,3.20 \pm 0.20$ and $2.75 \pm 0.06 \%$ ), respectively. These results are in accordance of data obtained by Ramadan, et al.(2010) and Soliman ( 2004). They found that the fiber content of sweet potato flour, pumpkin flour and corn was 4,94 \pm 0.77 , $3.50 \pm 1.32$ and $2.34 \pm 0.01 \%$, respectively .

Table (2): Chemical composition of the ingredients used in blends preparation on corn

snacks (on D.W basis).

\begin{tabular}{||c||c|c|c|c|c|c||}
\hline \hline Samples & Moisture $\%$ & Protein $\%$ & Fat $\%$ & Ash\% & Fiber $\%$ & Carbohydrate $\%$ \\
\hline \hline Corn grits & $10.58 \pm 0.03$ & $9.35 \pm 0.02$ & $3.28 \pm 0.03$ & $1.93 \pm 0.03$ & $2.75 \pm 0.06$ & $82.69 \pm 0.08$ \\
\hline S.P. Grits & $10.19 \pm 0.27$ & $4.48 \pm 0.02$ & $1.30 \pm 0.20$ & $3.58 \pm 0.02$ & $5.12 \pm 0.05$ & $85.53 \pm 0.28$ \\
\hline P.P. Grits & $8.82 \pm 0.05$ & $3.75 \pm 0.05$ & $2.17 \pm 0.02$ & $6.30 \pm 0.30$ & $3.20 \pm 0.20$ & $84.58 \pm 0.45$ \\
\hline \hline
\end{tabular}

Dry weight basis ( D.W. basis ) Sweet potato grits (S.P. )

Pumpkin grits (p.p.)

\pm SD Each value is the mean of triplicate.

\section{Extrusion processing:-}

\section{Effect of extrusion conditions on the physicochemical properties:-}

Effect of extrusion conditions such as : feed moisture content $(16,18$ and 20\%), screw speed (120, 140 and 160), and temperature (130, 150 and $170{ }^{\circ} \mathrm{C}$ ) on physicochemical properties such as : expansion ratio (ER), bulk density (BD), water solubility index \% (WSI\%) of extrudate products (blend 1 and 2), had showed in Tables (3 and 4) and Fig 2and 3. Effect of extrusion condition on expansion ratio were tabulated at the same Tables, the expansion values were ranged from 2,01 to 1,85 and 2,81 to $2,53\left(\mathrm{~g} / \mathrm{cm}^{3}\right)$ for snacks blend 1 and 2 so, the swelling percentage were -9.0 and -11.0 , respectively. When increasing the feed moisture content to $20 \%$, speed screw ( $160 \mathrm{rpm})$ and temperature $\left(170{ }^{\circ} \mathrm{c}\right.$ ) lead to a sharp decrease in expansion values $\left(1,85\right.$ and $2,53 \mathrm{~g} / \mathrm{cm}^{3}$, respectively for blend 1 and 2$)$. This agreement with Ding et al . (2005)they found that when increased feed moisture rate to decrease in expansion values and this was reflected in the 
form of snacks resulting from the blends 1 and 2 were long, crooked, dry and solid are shown in Fig. 2 and 3. Whilest, the best expansion ratio was $2.01 \mathrm{~g} / \mathrm{cm}^{3}$ and $2.62 \mathrm{~g} / \mathrm{cm}^{3}$, respectively and the swelling percentage was 3.5 and $3.4 \%$, respectively for snacks blend 1 combination of $16 \%$ moisture $130^{\circ} \mathrm{c}$ and $120 \mathrm{rpm}$ and snacks blend 2 combination of $18 \%$ moisture, $150^{\circ} \mathrm{c}$ and $140(\mathrm{rpm})$ and this was reflected in the form of snacks resulting from the blends 1 and 2 were long and swollen are shown in Fig. 2and 3. Meanwhile, the rate of expansion was 1.85 and $2.53\left(\mathrm{~g} / \mathrm{cm}^{3}\right)$, respectively, were $2.01 \mathrm{~g} / \mathrm{cm}^{3}$ and $2.62 \mathrm{~g} / \mathrm{cm}^{3}$ respectively and the swelling percentage were 4.6 and $6.8 \%$ respectively for snacks blend $1 \& 2$ when snacks blend 1 combination of $18 \%$ moisture , 150] c and $140 \mathrm{rpm}$ and snacks blend 2 combination of $16 \%$ moisture, 130 c and 120(rpm) and this was reflected in the form of snacks resulting from the blends 1 was long, thin and crooked while form of blends 2 was short, crooked, and dry are shown in Fig. 2and 3 this decrease in expansion values could be accounted for by the low moisture content, which may restrict the material flow inside the extruder barrel ,residence time, which would perhaps alter the extent of starch gelatinization and hence, the extrudate expansion ( Colonna et al ., 1984 and Kannadhason et al ., 2009 ). The obtained results were in agreement with those found by (Rolfe et al., 2001, they reported that the expansion rate of final extrudate products increased with decreasing the moisture content of feed material. The highest expansion rate attained at 16-17\% moisture content while the lowest expansion rate attained at 20$25 \%$ moisture content.

Also data in Tables3 and 4 and Fig 2 and 3 revealed that The main effects on the Bulk Density (BD) of extrudates:- Bulk density is a property which describes the weight of an ingredient per unit volume and thus affects transportation and storage costs. It is an important factor to consider when determining the storage volume of transport vehicles. Vessels and containers (UsGraine Council. 2008). Results indicated that the bulk density values were increased gradually from 0.27 to $0.31 \mathrm{~g} / \mathrm{cm}^{3}$ and 0.30 to 0.40 $\mathrm{g} / \mathrm{cm}^{3}$, respectively for snacks blend 1 and 2 , the highest bulk density values were found snacks blend $1 \& 2$ of the feed moisture content to $20 \%$, screw speed to $160 \mathrm{rpm}$ and barrel temperature to $170 \mathrm{o} \mathrm{C}$, while the lowest values was observed for the treatment combination of 130 o C, $120 \mathrm{rpm}$ and $16 \%$ 
moisture. This may be due to relationship between the moisture content and temperature intake , starch gelatinization and bulk density (Mercier et al., 1989 ,also the bulk density has been linked with the expansion ratio in describing the degree of puffing in extrudates (Asare et al., 2004). It can be seen that expansion rate did not definite pattern. The reason for this observation when the feed moisture contents of the blends increase, extrusion temperature drops and les expansion occurs in the extrudate.

Also, the effect of extrusion condition on water solubility index $\%$ (WSI \%) was summarized at Tables 3 and 4 and Fig 2 and 3 . WSI\% measures the degree of starch conversion during extrusion which is the amount of soluble polysaccharide released from the starch components after extrusion ( Kirby et al \& Smith, 1988 and Sriburiet al ., 1999) . Feed rate, feed moisture and temperature were found to have effect on the WSI\% of snacks blend 1and2. Increasing feed rate, feed moisture content and barrel temperature decreased the WSI\% of snacks blend 1and 2from 19.70 to 14.06 and 18.68 to $12.69 \%$, respectively, these results are in agreement with (Rosentrater et al., 2009). who mentioned that increasing of moisture content decreased the WSI\% and these values are similar with (Ding et al., 2005 ) they found the values WSI\% ranged between $15.73 \pm 1.11$ to $37.19 \pm$ $0.38 \mathrm{~g} / \mathrm{d}$

Table (3): The effect of extrusion condition on the physicochemical properties of blend 1 .

\begin{tabular}{|c|c|c|c|c|c|c|}
\hline \multirow{5}{*}{$\frac{\bar{D}}{\frac{D}{0}}$} & \multicolumn{3}{|c|}{ Conditions } & \multirow{2}{*}{$\begin{array}{c}\text { ER } \\
\left(\mathrm{g} / \mathrm{cm}^{3}\right)\end{array}$} & \multirow{2}{*}{$\begin{array}{c}\text { BD } \\
\left(\mathrm{g} / \mathrm{cm}^{3}\right)\end{array}$} & \multirow[t]{2}{*}{ WSI \% } \\
\hline & $\mathrm{T}^{\circ} \mathrm{C}$ & M \% & $\mathrm{S}(\mathrm{rpm})$ & & & \\
\hline & 130 & 16 & 120 & 2.01 & 0.27 & 19.70 \\
\hline & 150 & 18 & 140 & 1.94 & 0.29 & 16.45 \\
\hline & 170 & 20 & 160 & 1.85 & 0.31 & 14.06 \\
\hline
\end{tabular}




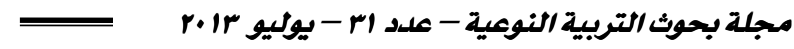

Table (4): The effect of extrusion condition on the physicochemical properties of blend 2 .

\begin{tabular}{|c|c|c|c|c|c|c|}
\hline \multirow{5}{*}{$\frac{\text { Dै }}{\frac{0}{0}}$} & \multicolumn{3}{|c|}{ Conditions } & \multirow{2}{*}{$\begin{array}{c}\text { ER } \\
\left(\mathrm{g} / \mathrm{cm}^{3}\right) \\
\end{array}$} & \multirow{2}{*}{$\begin{array}{c}\mathrm{BD} \\
\left(\mathrm{g} / \mathrm{cm}^{3}\right) \\
\end{array}$} & \multirow[t]{2}{*}{ WSI\% } \\
\hline & T. ${ }^{\circ} \mathrm{C}$ & M\% & $\mathrm{S}(\mathrm{rpm})$ & & & \\
\hline & 130 & 16 & 120 & 2,81 & 0.30 & 18.68 \\
\hline & 150 & 18 & 140 & 2.62 & 0.35 & 15.33 \\
\hline & 170 & 20 & 160 & 2.53 & 0.40 & 12.69 \\
\hline
\end{tabular}

Blend $1=95 \%$ corn grits and $5 \%$ sweet potato grits

Blend $2=95 \%$ corn grits and $5 \%$ pumpkin grits.

Expansion rate(ER) $\mathrm{g} / \mathrm{cm}^{3}$

Water soluble index \% (WSI \%)

Feed moisture (M \%)
Bulk density ( B D) $\mathrm{g} / \mathrm{cm}^{3}$.

Temperature (T. $\left.{ }^{\circ} \mathrm{C}\right)$

Screw speed $=\mathrm{S}(\mathrm{rpm})$

\begin{tabular}{|c|c|c|}
\hline \multicolumn{3}{|c|}{ Temperature ${ }^{\circ} \mathrm{c}$} \\
\hline $130{ }^{\circ} \mathrm{c}$ & $150^{\circ} \mathrm{c}$ & $170^{\circ} \mathrm{c}$ \\
\hline \multicolumn{3}{|c|}{ Screw Speed (rpm) } \\
\hline 120 & 140 & 160 \\
\hline $16 \%$ & $18 \%$ & $20 \%$ \\
\hline
\end{tabular}

Fig .2. Effect of moisture, temperature and screw speed on expansion rate of the

Blend 1 consists of (95\% corn grits and 5\% sweet potato grits).

\begin{tabular}{|c|c|c|}
\hline \multicolumn{3}{|c|}{ Temperature ${ }^{\circ} \mathrm{c}$} \\
\hline $130 \% \mathrm{c}$ & $150^{\circ} \mathrm{c}$ & $170^{\circ} \mathrm{c}$ \\
\hline \multicolumn{3}{|c|}{ Screw Speed (rpm) } \\
\hline 120 & 140 & 160 \\
\hline \multicolumn{3}{|c|}{ Moisture \% } \\
\hline $16 \%$ & $18 \%$ & $20 \%$ \\
\hline
\end{tabular}

Fig .3Effect of moisture, temperature and screw speed on expansion rate of theBlend 2 consists of (95\% corn and 5\% pumpkin) 


\section{Effect of storage period on the extrudate quality}

Sensory evaluation of extruded yellow corn grits and corn, sweet potato and pumpkin. One of the limiting factors of consumer acceptability is the organoleptic properties including, color, taste, crispness, appearance and overall sensory aspects of consumer performance. Data concerning the organoleptic properties scores of different products stored at room temperature for three months are represented in Table (5) and fig(6). Results in Table (5) and fig(6) show that the best color is blend 2 (5\% pumpkin, and $95 \%$ corn), which has highest score $(8.90 \pm 0.51)$. Taste is a major criterion affecting the quality of any final extruded products. The results in Table (5) indicated that , the highest taste $(9.10 \pm 0.32)$ was given to the products 2 ,

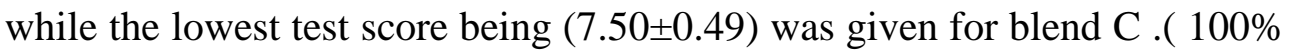
corn). Results in Table (5) showed that the best appearance is blend1(5\% sweet potato, and 95\% corn), that had the highest score was given $(8.80 \pm 0.59)$. The lowest score $(7.90 \pm 0.29)$ was given for blend 1.The data in the same table showed that crispness of the extrudates blend 1 had higher scores $(8.49 \pm 0.47)$ than blend c. (the $100 \%$ corn only) which had given the lowest score (7.40 \pm 0.46$)$, because of the corn blends had no crispness and appeared to be smooth in texture . Results concerning effect of storage period and type are shown in of Table (5) and fig (6). These results indicate that there were no significant changes in color for extruded blends. After three months of storage and the changes were very meager for taste was still very palatable. The overall acceptability scores for all blends were still very good prolonged storage period. However no obvious changes in the appearance was given for extrudates, so, the products crispiness had almost the same score zero time and after three months of storage .These results were in agreement with Siam(1999)who reported that a rice- faba bean (6:4) blends could be stored without any change for six months either at $22{ }^{\circ} \mathrm{C}$ or under simulated hot/humid field condition $\left(38{ }^{\circ} \mathrm{C} / 90 \% \mathrm{RH}\right)$. Also , Hussein (2000) found that no significant changes for 3 months of storage at room temperature. Also from the same tables, there are un significant differences between the taste, color, appearance and crispness samples at 
$\mathrm{P} \leq 0.01$ for stored after 3 month. It can be concluded that snacks was quite acceptable by the panelists.

Conclusion: the physicochemical properties and sensory characteristics of corn extrudates or corn snacks on one -s crow extrusion process depend on process variable such as feed rate, feed moisture and barrel temperature had effect on various extrudate namely, expansion ratio, bulk density and water bulk density percentage .

Table (5):The effect of storage period on the sensory evaluation of different extruded blends.

\begin{tabular}{|c|c|c|c|c|c|c|c|c|c|c|}
\hline \multirow{3}{*}{$\begin{array}{c}\text { Blend } \\
\text { No. }\end{array}$} & \multicolumn{10}{|c|}{ Sensory Evaluation } \\
\hline & \multicolumn{2}{|c|}{$\begin{array}{c}\text { Color } \\
10\end{array}$} & \multicolumn{2}{|c|}{$\begin{array}{c}\text { Taste } \\
10\end{array}$} & \multicolumn{2}{|c|}{$\begin{array}{c}\text { Appearance } \\
10\end{array}$} & \multicolumn{2}{|c|}{$\begin{array}{c}\text { Crispness } \\
10\end{array}$} & \multicolumn{2}{|c|}{$\begin{array}{c}\text { Over } \\
\text { Acceptability } \\
10\end{array}$} \\
\hline & 0 time & $\begin{array}{c}3 \\
\text { month } \\
\end{array}$ & $\begin{array}{c}0 \\
\text { time } \\
\end{array}$ & 3 month & 0 time & 3 month & 0 time & $\begin{array}{c}3 \\
\text { month } \\
\end{array}$ & 0 time & 3 month \\
\hline \multirow{3}{*}{ C } & 7.94 & 7.70 & 7.50 & 7.41 & 8.51 & 8.30 & 8.49 & 8.43 & 8.12 & 7.97 \\
\hline & \pm & \pm & \pm & \pm & \pm & \pm & \pm & \pm & \pm & \pm \\
\hline & 0.61 & 0.50 & 0.49 & 0.50 & 0.31 & 0.32 & 0.47 & 0.48 & 0.43 & 0.42 \\
\hline \multirow{4}{*}{1} & * & & $* * *$ & $* * *$ & * & $*$ & $* * *$ & $* * *$ & & \\
\hline & 8.40 & 8.04 & 8.60 & 8.41 & 8.80 & 8.70 & 7.40 & 7.30 & 8.31 & 8.12 \\
\hline & \pm & \pm & \pm & \pm & \pm & \pm & \pm & \pm & \pm & \pm \\
\hline & 0.29 & 0.46 & 0.51 & 0.45 & 0.59 & 0.60 & 0.46 & 0.45 & 0.42 & 0.44 \\
\hline \multirow{4}{*}{2} & $* * *$ & $* * *$ & $* * *$ & $* * *$ & $* *$ & $* *$ & & & $*$ & $*$ \\
\hline & 8.90 & 8.70 & 9.10 & 9.00 & 7.90 & 7.70 & 8.30 & 8.10 & 8.56 & 8.44 \\
\hline & \pm & \pm & \pm & \pm & \pm & \pm & \pm & \pm & \pm & \pm \\
\hline & 0.51 & 0.52 & 0.32 & 0.29 & 0.29 & 0.31 & 0.32 & 0.26 & 0.29 & 0.30 \\
\hline
\end{tabular}

Each value in the mean \pm SD Significant with control group $* \mathrm{p}<0.05 * * \mathrm{p}<0.01$ $* * * \mathrm{p}<0.001$

Blend $\mathrm{C}=100 \%$ corn grits $($ control) Blend $1=95 \%$ corn grits $+5 \%$ sweet potato grits Blend $2=95 \%$ corn grits $+5 \%$ pumpkin grits 


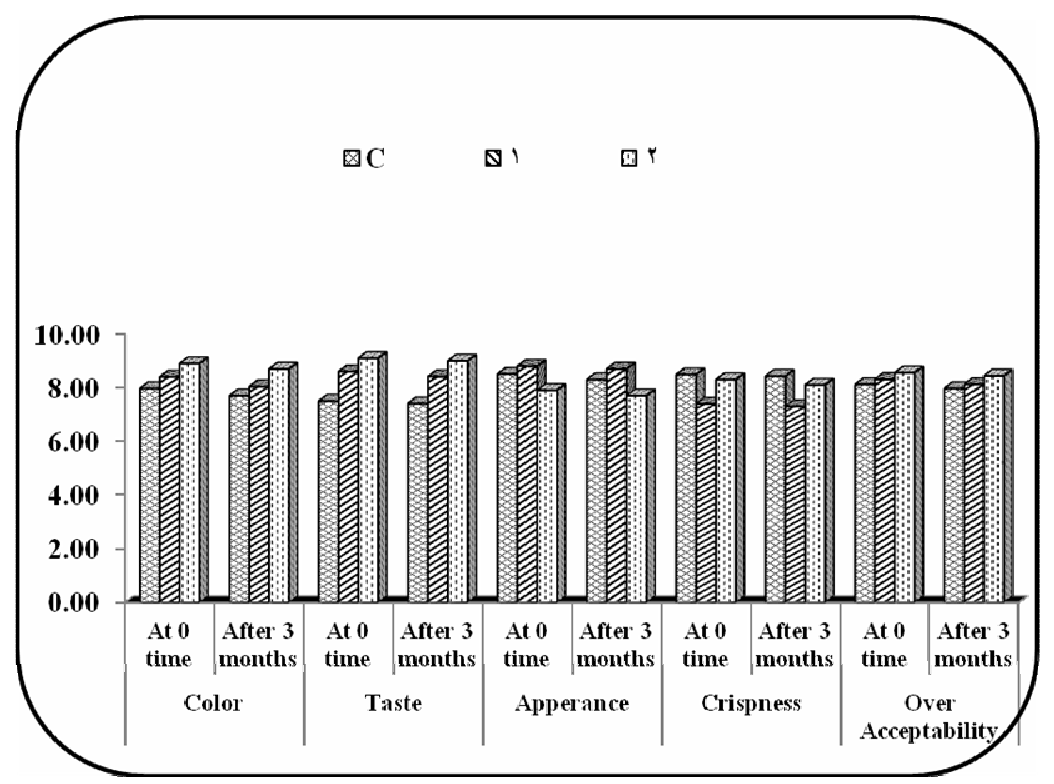

$\mathrm{C}=100 \%$ corn grits

Blend $1=95 \%$ corn grits $+5 \%$, sweet potato.

Blend $2=95 \%$ corn grits $+5 \%$ pumpkin . 


\section{REFERENCES}

- A.O.A.C.( 2000) : Association of official analytical chemists . official methods of analysis 17th ed. AOAC, Washington,DCC,USA

- Ahmed, M. Akter, S. and Jong , B.S. (2010): Effect of pretreatment and drying temperature on sweet potato flour . International Journal of Food science and technology, vol. 24 ( 4) 626 - 732 .

- Alibas, I. (2007): Microwave, air and combined microwave-air-drying parameters of pumpkin slices. LWT 40(8), 1445-1451.

- Alton. A, Mccarthy. K, Maskan. . (2007): Evaluation of snack foods from barley. Tomato pomace blends by extrusion processing, Department of food Enginerring, university of baziantep, GaziantepTR-27310, Turkey.

- Anderson, V., Hedlund, B., Jonsson, L. and Sevenss S. (1981): Biological active substances in soy products in soy protein and human nutrition by Wilcke1-1.L., Hopkins D.T. and Waggle D. Academic, New York.

- Arévalo-Pinedo, A. and Murr, F. E. X. (2006): Kinetics of vacuum drying of pumpkin (Cucurbita maxima): modeling with shrinkage. Journal of food Engineering 76, 562-567.

- Asare, E. K., Sefa-Dedeh , S ., Sakyi-Dawson, E. O. (2004): Application of response surface methodology for studying the product characteristics of extruded rice-cowpea-groundnut blends. International. Journal of food sciences and Nutrition, 55, 431-439.

- Bates , R.P. ; Gvaham ,H .O.; Mattew , R.F. and close, L.R. ( 1991:Bread fruit chips : Preparation, stability and acceptability .J. Food Sci.5d( 6) : 1608- 1610.

- Burn, D.(2007): On therise. Food in candada, 67(1), 28-32.

- Colonna, P.,J.L. Doublier ,J.P. Melcipn, F.de Moredonand C. Mercier. ( 1984) Extrusion cooking and drum drying of wheat starch . I .physical and macromolecular modification Cereal Chem.,61: 538-543.

- Desrumaux, A.; Bouvier, J. M. and Burri. J. (1999): Effect of free fatty acids addition on corn grits extrusion cooking . Cereal chemistry. 76, 699-704.

- Ding, Q- B.; Ainsworth. P.; Tucker. G. and Marson, H. (2005): The effect of extrusion conditions on the physicochemical properties and sensory 
characteristics of rice. Based expanded snacks : Hollings faculty, the university of Nottingham, university. Old Hall Lane, Manchester M146 HR.UK.

- Dijksterhuis, G., Luyten, H., Wijk, R and Mojet, J . (2005): A new sensory vocabulary for crisp and crunchy dry model foods . Department of food quality , consumer and market insight, P.O. Box 17, 6700 AA Wageningen, The Netherlands.

- Egyptian Organization for Standardization and quality (EOSQ 1525 ) ( 2005 ) Corn Snacks Products ,Ministry of Trade and Industry .Egypt.

- Food and Agriculture Organization of the united nations (FAO). ( 2006 ) : FAO statistics database - Agriculture, Rome, Italy ,Available from www.fao. Org.

- Grabowski , J .A., Truong, V . D. , and Daubert , C. R. ( 2008 ): Nutritional and rheological characterization of spray dried sweet potato powder, LWT- Food Science and Technology pp . 206-216.

- Gujska, E. and Khan, K . (1990): extrudates from high. Starch fraction of navy. Pinto and garbanzo beans .J. Food sci ,ss(2): 466-469.

- Hussein E. H. (2000): Chemical and nutritional evaluation of high protein extrudates. P1-1. D. Thesis, Fac. Of Home Economic, Minufiya Univ.

- Iio, S.; Liu, .Y. and Berghofer. (1999): Extrusion cooking of rice flour and amaranth blends, Lebenem. Wiss U- technol., 32,79.88.

- Jun , H. ; Lee , C. ; Sond , G. and Kim , K. . (2006): Characterization of pectin polysaccharide from pumpkin peel . Lebensm Wiss Technol. , 39:554-61 .

- Kannadasone, s., Muthukmarappan ,k., and Rosentrotrater, kort A. ( 2009 ) : Effect of Ingredient and Extrusion Parameters on AquafeedsContaining DDGS and Tapioca Starch. J. of aquaculture Feed Science \& Nutrition 1 (1): 6-21..

- King, J. (2006): Nutrition bar update .Nutraceuticals, world, 9(1), 32-36.

- Kirby, A.R., Ollett, A.L., Parker, r.,\& Smith, A.C.(1988) An experimental study of screw configurations effect in the twin-scrow extrusion-cooking of maize grits .Journal of FOOD Engineering ,8, 247-272.

- Lue, S., Hsieh, F., Peng, I. C. and Huff, H.E.(1990): Expansion of corn extrudates containing dietary fiber: A microstructure study. LebensmWissTecl., 23(2):65-173.

- Luyten, H., Lichtendonk, W., Vanvliet, T ., Castro. E.M. and visser, J. (2004): Acoustic emission from crispy/ crunchy foods to link mechanical properties and 
sensory perception. In E-Dickinson (Ed), food calloids: interactions microstructure and processing (pp. 380-392), Harrogate Uk.

- Marck, G.; Radzanowska, J.; Danilcenko, H.; Jariene, E.; Cerniauskiene, J.(2008): Quality of pumpkin cultivars in relation to sensory characteristics journal of Warsaw University of life sciences, Nowoursynowska 166. 02-787 Warszawa, Poland.

- Martin. C. P, San .Z.T, Steringa.D.W ,Salvador.D.W, Fiszman. S. M, and Viet T.V .(2010): Performance of cellulose derivatives in deep. Fried battered snacks : Oil barrier and crispy properties . Journal of food science. 3600-3700. The Nether Lands.

- Méot , J. M., Marouzé, C., Rivier, M.(2007) : Csecgt : Un séchoir pour les produits granules . principes et method de dimensionnement. Transformation , conservation et qualité des aliments; une Nouvelle approche de la lute contre la pauvrétéséminaire regional organize du 21 au 23 November 2007 par Agenceuniversitaire de la francophnie et université Cheikh Anta Diop de Dakar. Auf, Dakar. France.

- Mercier, C. Linka, P and Harper , J. M .(1989): Extrusion cooking American Asso, of cereal chemists, Inc . Stipaul, Minnesota, USA.

- Meuser, F.; and Van Lengerich, B.(1992):System analytical model for the extrusion of starches. In J. L. Kokini, C. Ho and Larwe (Eds). Food extrusion science and technology (PP. 619-630). New York: Marcel Dekker Inc.

- Oliveira, M. A., Moller, S. H, Halland, H and Rosenlund, G . (1992) : The effects of process parameters on expansion of extruded fish feeds.food extrusion science and technology . In: Kokini, J. L. and Karwe M.V. (Eds). Marcel Dekker, New york, pp: 693-709, ISBN: 082478528.

- Onwulata, C. I. and Konstance, R. P.(2006): Extruded corn meal and whey protein concentrate : Effect of particle size. Journal of food processing and preservation 30.475-487.

- Ramadan, Afaf-haniem M.; Abd-El-kader, A .A. and Abd-Alla, M.M. (2010): Producing biscuits enriched with vitamin A and Iron by using sweet potato and pumpkin powder for primary school children .J .Food and Dairy Sci. , Mansoura University, Vol. ( 8) : 471-481,2010 . 
- Regilda , S. R.; Moreira-Araujo.; Marcos. A.M.; Arraujo and Jose, A. G.; Areas .(2007): Fortified food made by the extrusion of a mixture of chickpea. Corn and boving lung controls iron deficiency anaemia in pre schoolchildren, universidade de saopoulo, de partamento de nutricao. Av. Dr. Arnaldo, 715, CEP 01246. 904, sao Paulo, Brazil.

- Rolfe, L .A., Huff, H.E and Hseih, F. (2001): Effects of particle size and processing variables on the properties of an extruded catfish feed. J. Aqua . Food prod . Tech., 10(3): 21-33. Dol: 10.1300/J030v10n03_03.

- Rosentrater, K. A., Muthukumarappan, K and Kannadhason, S. (2009): Effects of ingredients and extrusion parameters on aquafeeds containing DDGS and potato starch. Department of Agricultural and Biosystems Engineering, South Dakota State University, Brooking, sd 57007, USA.

- Rouelaut, G., Dacremont, C., Vales Pamies, B., Colas, b., and Le Meste, M. (2002): Vales crispness: a critical review on sensory and material science approaches. Trends in food science and technology, 13, 217-227.

- Sajilata, M, G.; Singhal, R, S. (2004): Specialty starches for snack foods. Department of food and fermentation technology, Institute of chemical technology, University of Mumbai, Nathala Parekh Marg, Matunga, Mumbai400 019, India.

- SPSS. (2007). Statistical Package for Social Science program version 17 for Windows, SPSS

- Inc, Chicago, IL, USA.

- Soliman ,A. A. A. (2004) : Quality attributes of extruded high protein blends . $\mathrm{Ph}$. D . Thesis, Faculty of Home Economic, Minufiya Univ.

- Siam, M.A.M .(1999): Formulation and evaluation of novel foods based on cereal/legume blends. Ph. D. Thesis, Fac. Of Agric. Alex. Univ.

- Sriburi, P., Hill, S. E. and Barclay, F. (1999): De polymerization of cassava starch .Carbohyd .Polym ., 38: 211-218. Dol: 10.1016/s0144-8617(98)00093-9.

- Stojceska , V .; Ainsworth. P.; Plunkett. A. and Ibanoglu . S. (2008): The recycling of brewer's processing by-product into ready-to-eat snacks using extrusion .Technology .Journal of cereal science, 47, 469-479.

- Utomo .J.S., Chem., Y. B. Rahman ,R.A ., and Saad , M.S. ( 2005) : The effect of shape blanching methods and flour on characteristics of restructured sweet 
potato stick international journal of food science and technology ,43, 18961900.

- Us Grains Cuncil. (2008):Use of DDGS in aquaculture diets .DDGS user Hand book.http://www.grains.org/galleries/DDGS\%

20user\%20Hanbook/06\%20.\%zouse\%20of\%20DDGS\%zoin\%20Aquacuture. $\% 2$ ODiets.pdf .

- USDA. 1999. Pratical procedures for grain handlers: Inspecting Grain. Untied States Department of Agriculture-Grain Inspection, Packers and Stockyards Administration . http://151.121.117/pubs/primer.pdf.

- Vincent, J.F.V. (1998): The quantification of crispness. Journal of the science of food and Agriculture. 78, 162-168.

- WHO. (2004): Obesity prevalent and managing the Global Epidemic. Report of WHO consultation in obesity, Geneva, June 30. World Health Organization , Geneva.

- Zaky, M.S. (2000): Technological and biological studies on carrot and sweet potato. Ph. Thesis food science and technology Dept ., Fac. of Agric. Ain Shams university. 


\title{
تأثير استخدام هجروش البطاطا والقرع العسلي على إنتاج هقرهشات الذرة باستخدام البثق الحراري
}

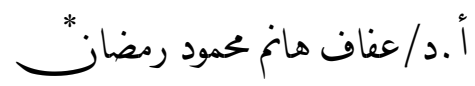

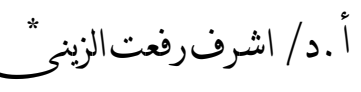 \\ * م-م/حنازعلى إبومندور \\ أ. أد /عزت محمد ابراهيم عابديمن
}

الملخص العربي :

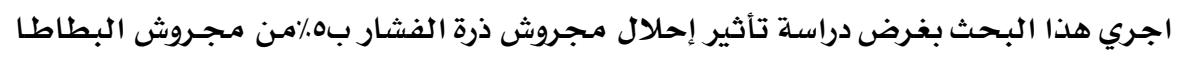

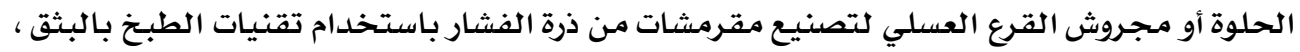

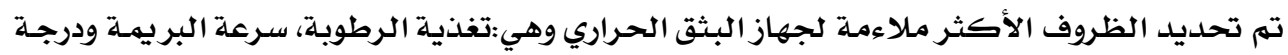

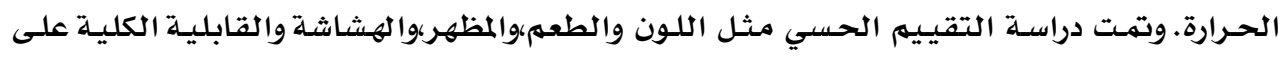

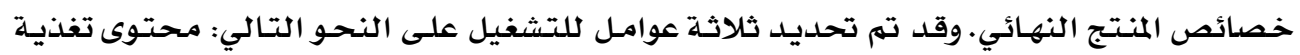

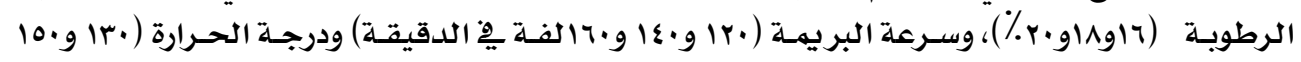

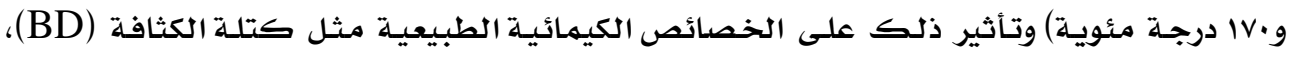

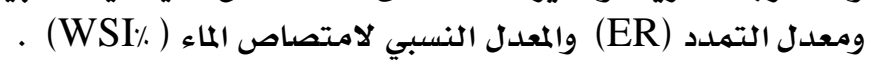

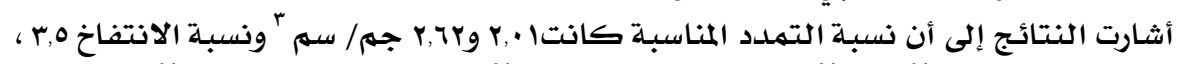

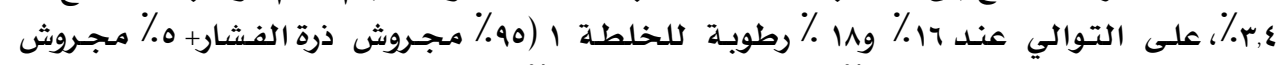

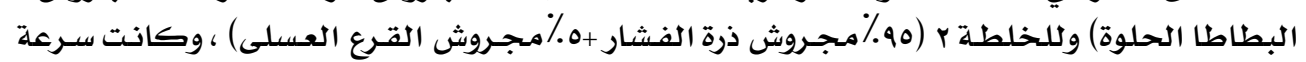

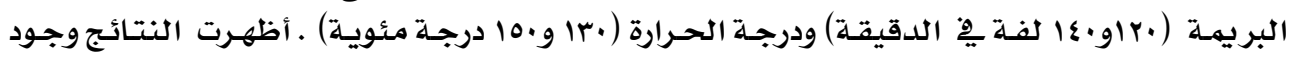

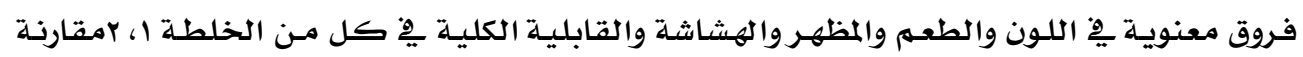

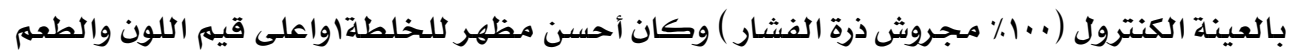

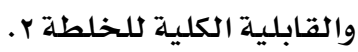

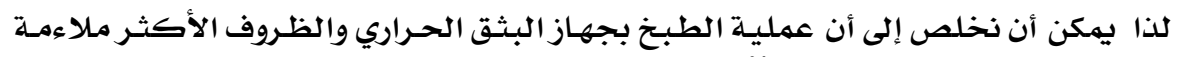

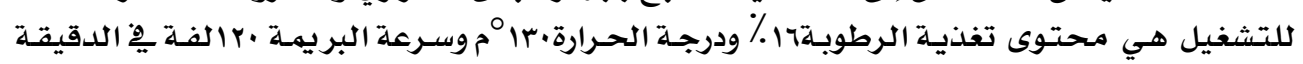

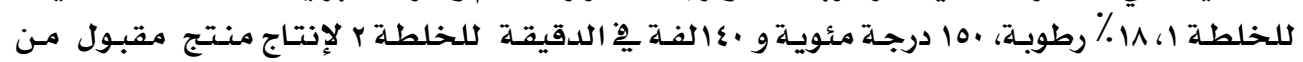

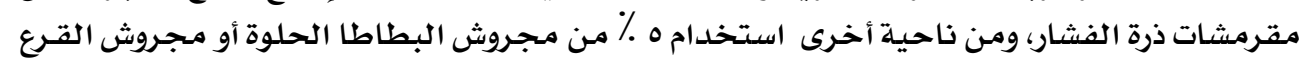

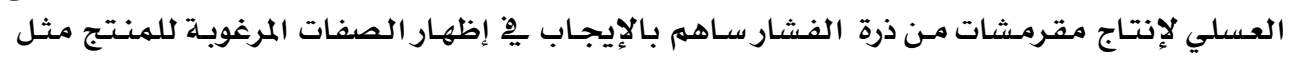

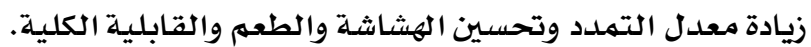

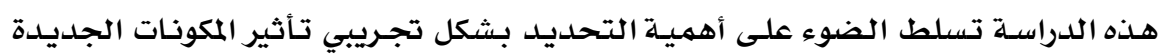

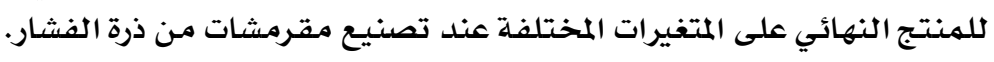

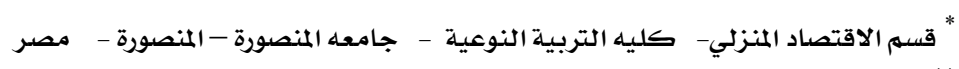

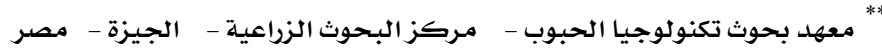

